\title{
Emerging therapies in pipeline for chronic hepatitis $\mathrm{C}$
}

\author{
Navjot Kaur*, Harish Negi, Avaneesh Pandey
}

Department of Pharmacology, Post Graduate Institute of Medical Education \& Research, Chandigarh-160012, India

Received: 10 July 2013

Accepted: 22 July 2013

*Correspondence to:

Dr. Navjot Kaur,

Email: navjotpgi1@yahoo.com

(C) 2013 Kaur N et al. This is an openaccess article distributed under the terms of the Creative Commons Attribution Non-Commercial License, which permits unrestricted noncommercial use, distribution, and reproduction in any medium, provided the original work is properly cited.

\begin{abstract}
Hepatitis C infection represents a major global public health problem; as it leads to significant morbidity, mortality, and financial burden on healthcare system. According to world health organization, nearly 2- 3\% (130-170 million) of the world's population has been infected with hepatitis C. The current standard therapy is limited both in efficacy and tolerability which highlights the large unmet medical need in this area. Recent advances in the understanding of lifecycle of hepatitis $\mathrm{C}$ virus and host cell interactions have led to the identification of multiple novel antiviral targets. Intense research effort is currently being directed towards translating these targets into developing more efficacious and safe treatment options for patients living with HCV infection. Current review aims to discuss the emerging therapies in pipeline for chronic hepatitis $\mathrm{C}$ outlining their mode of action and current stage of development in clinical trials.
\end{abstract}

Keywords: Cyclophillin inhibitors, Direct acting antivirals, Hepatitis C, Novel targets, Sofosbuvir

\section{INTRODUCTION}

Hepatitis $\mathrm{C}$ is prevalent worldwide. For most countries, the prevalence of $\mathrm{HCV}$ infection is $<3 \%$. For some countries in Asia and Africa prevalence is higher (up to $15 \%)$ and highest (>15\%) prevalence has been reported in Egypt where the disease is endemic. ${ }^{1}$ Causative agent is a positive-strand RNA virus that infects liver and can lead to both acute and chronic hepatitis. Most of acute HCV infections remain asymptomatic and patients are often diagnosed in chronic hepatitis phase. Out of chronically infected individuals $60-70 \%$ suffers from chronic liver disease, with as many as $20 \%$ developing cirrhosis and 1 $5 \%$ patients dying as a result of cirrhosis or liver cancer. ${ }^{2}$ Chronic HCV infection has been recently reported as leading cause of liver transplantation and second most common cause of liver cancer worldwide. ${ }^{3-5}$ The economic costs of hepatitis $\mathrm{C}$ are enormous as in low prevalence country like US alone, the estimated cost exceeds US\$600 million annually, which is projected to further rise in the coming years. ${ }^{6}$

For the past two decades, standard of care for chronic hepatitis C patients included 24-48 weeks of therapy with combination of interferon alpha (PEG-IFN $\alpha$ ) and ribavirin (RBV). Duration of therapy was based on $\mathrm{HCV}$ genotype: 48 weeks for genotypes 1, 4 and 24 weeks for genotypes 2, 3. This dual therapy was capable of inducing sustained virologic response (SVR) in only 40$50 \%$ for genotype 1 and up to $70-80 \%$ in genotypes 2 and 3 infections. ${ }^{7,8}$ Moreover, it is often poorly tolerated, leading to treatment discontinuation in $10 \%$ of the patients while upto $40 \%$ of the patients require dose reduction or temporary interruption of PEG-IFN $\alpha / \mathrm{RBV}^{9}$ Reported adverse events include flu-like symptoms, bone marrow depression, psychiatric symptoms, hemolytic anemia and autoimmune reactions. ${ }^{10}$ Once achieved, an SVR is associated with long-term clearance of $\mathrm{HCV}$ infection, which is regarded as a virologic cure, with improved morbidity and mortality. ${ }^{11-13}$ Boceprevir and telaprevir, which were approved in Europe and US in 2011 are currently used as a part of triple therapy for genotype $1 \mathrm{HCV}$ infections. Though use of these first generation protease inhibitors in combination with PEGIFN and RBV, improves effectiveness and increases the cure rate to up to $75 \%$ in patients infected with $\mathrm{HCV}$ genotype-1, but it is limited by increased incidence of serious adverse events (38-48\%), including severe 
anaemia, liver decompensation and sepsis. ${ }^{14-17}$ Anaemia and dysguesia are frequently seen with boceprevir and telaprevir is associated with mild to severe skin rashes. Another limitation is numerous potential drug- drug interactions due to inhibition of CYP450 and Pglycoprotein besides increasing complexity of dosing regimens. ${ }^{18}$ Therefore, there is continuing need of newer therapies that promise further improvements in virologic response rate with improved tolerability and reduced duration of therapy. Current review aims to discuss the emerging therapies in pipeline for chronic hepatitis $\mathrm{C}$ outlining their mode of action and current stage of development in clinical trials.

\section{Emerging Therapies}

According to a recent systematic review there are more than 50 molecules currently in development to treat chronic HCV. ${ }^{19}$ These molecules are broadly classified as those that target viral replication directly or those which target host cell proteins that are essential for viral replication. Many drugs targeting viral proteins involved in different steps of viral replication including NS3/NS4A protease, NS5B polymerase and NS5A protein are currently being investigated in clinical trials (as shown in Table 1). Cyclophillin inhibitors and antagomirs on the other hand target host cell proteins. Newer analogues of interferon and ribavirin are also in clinical development.

Table 1: Emerging therapies for the treatment of chronic hepatitis $\mathrm{C}$ infection.

\begin{tabular}{|c|c|c|c|c|c|c|c|}
\hline \multirow{3}{*}{$\begin{array}{l}\text { Therapeutic } \\
\text { classes in } \\
\text { development }\end{array}$} & \multicolumn{5}{|c|}{ Direct acting antivirals } & \multicolumn{2}{|c|}{ Host targeting antivirals } \\
\hline & \multicolumn{2}{|c|}{ NS3/4A protease inhibitor } & \multicolumn{2}{|c|}{ NS5B polymerase inhibitors } & \multirow[t]{2}{*}{$\begin{array}{l}\text { NS5A } \\
\text { inhibitors }\end{array}$} & \multirow[t]{2}{*}{$\begin{array}{l}\text { Cyclophillin } \\
\text { inhibitors }\end{array}$} & \multirow[t]{2}{*}{ Antagomirs } \\
\hline & $1^{\text {st }}$ gen & $2^{\text {nd }}$ gen & $\begin{array}{l}\text { Nucleos }(\mathrm{t}) \text { ide } \\
\text { analogue } \\
\text { Inhibitors }\end{array}$ & $\begin{array}{l}\text { Non-Nucleoside } \\
\text { Inhibitors }\end{array}$ & & & \\
\hline $\begin{array}{l}\text { Mechanism of } \\
\text { action }\end{array}$ & $\begin{array}{l}\text { Inhibit } \mathrm{HCV} \\
\text { processing at } \\
\text { immune resp }\end{array}$ & $\begin{array}{l}\text { olyprotein } \\
\text { impairs host } \\
\text { se }\end{array}$ & $\begin{array}{l}\text { Mimic natural } \\
\text { substrate of } \\
\text { polymerase; get } \\
\text { incorporated at } \\
\text { the active site of } \\
\text { enzyme leading to } \\
\text { direct chain } \\
\text { termination. }\end{array}$ & $\begin{array}{l}\text { Bind to different } \\
\text { allosteric sites, } \\
\text { resulting in } \\
\text { conformational } \\
\text { change in } \\
\text { polymerase before } \\
\text { formation of } \\
\text { elongation complex }\end{array}$ & $\begin{array}{l}\text { Inhibit } \\
\text { function of } \\
\text { membrane } \\
\text { bound } \\
\text { replication } \\
\text { complex, } \\
\text { virion } \\
\text { assembly } \\
\text { and release. }\end{array}$ & $\begin{array}{l}\text { Target host } \\
\text { cyclophillin } \\
\text { enzyme, } \\
\text { which is a } \\
\text { functional } \\
\text { regulator of } \\
\text { HCV } \\
\text { replication }\end{array}$ & $\begin{array}{l}\text { Inhibit } \\
\text { upregulation } \\
\text { of viral RNA } \\
\text { by binding to } \\
\text { host } \\
\text { microRNA- } \\
122\end{array}$ \\
\hline $\begin{array}{l}\text { Genotype } \\
\text { coverage }\end{array}$ & Genotype 1 & $\begin{array}{l}\text { Pan } \\
\text { Genotypic }\end{array}$ & Pan Genotypic & Genotype 1 & $\begin{array}{l}\text { Pan } \\
\text { Genotypic }\end{array}$ & Pan Genotypic & Genotype 1 \\
\hline $\begin{array}{l}\text { Barrier to } \\
\text { resistance }\end{array}$ & Low & High & High & Low & Low & High & High \\
\hline Advantages & $\begin{array}{l}\text { Potent } \\
\text { antiviral } \\
\text { activity } \\
\text { against } \\
\text { genotype 1 }\end{array}$ & $\begin{array}{l}\text {-Pan- } \\
\text { genotypic } \\
\text { antiviral } \\
\text { activity }\end{array}$ & $\begin{array}{l}\text {-High barrier for } \\
\text { resistance } \\
\text {-Pan Genotypic }\end{array}$ & $\begin{array}{l}\text { Effective against } \\
\text { genotype } 1\end{array}$ & $\begin{array}{l}\text {-Pan } \\
\text { Genotypic } \\
\text { activity }\end{array}$ & $\begin{array}{l}\text {-Pan } \\
\text { Genotypic } \\
\text {-High barrier } \\
\text { to resistance }\end{array}$ & $\begin{array}{l}\text { High barrier } \\
\text { to resistance }\end{array}$ \\
\hline Disadvantages & $\begin{array}{l}\text { Extensive } \\
\text { cross } \\
\text { resistance }\end{array}$ & - & Fewer in pipeline & $\begin{array}{l}\text { HCV genotype } \\
\text { dependent -Low } \\
\text { barrier to resistance }\end{array}$ & $\begin{array}{l}\text { Low genetic } \\
\text { barrier to } \\
\text { resistance }\end{array}$ & - & - \\
\hline \multicolumn{8}{|c|}{ Molecules in clinical development } \\
\hline Licensed & $\begin{array}{l}\text { Boceprevir } \\
\text { Telaprevir }\end{array}$ & - & - & - & & - & - \\
\hline Phase III & $\begin{array}{l}\text { Simeprevir } \\
\text { Faldaprevir } \\
\text { Asunaprevir }\end{array}$ & - & Sofosbuvir & & aclatasvir & Alisporivir & - \\
\hline Phase II & $\begin{array}{l}\text { Danoprevir } \\
\text { Sovaprevir } \\
\text { Vaniprevir } \\
\text { GS-9256 } \\
\text { GS-9451 } \\
\text { ABT-450 }\end{array}$ & MK-5172 & $\begin{array}{l}\text { Mericitabine } \\
\text { IDX-184 } \\
\text { PSI-7851 }\end{array}$ & $\begin{array}{l}\text { trobuvir } \\
\text { ibuvir } \\
\text { X-222; BMS- } \\
\text { 1325; ABT-333; } \\
\text { 3T-072; IDX-375; } \\
\text { 207127; VCH- } \\
6\end{array}$ & $\begin{array}{l}\text { ISK2336805 } \\
\text { ABT-267 } \\
\text { iS-5885 }\end{array}$ & $\begin{array}{l}\text { NIM- } \\
\text { 811;SCY-635 }\end{array}$ & Miravirsen \\
\hline
\end{tabular}




\section{DIRECT ACTING ANTIVIRAL AGENTS}

\section{NS3/4A protease inhibitors}

Non structural NS3/4A serine protease is an important target for antiviral therapy, as it plays two important roles favouring viral replication and persistence in the host. It is essential for post-translational cleavage of the viral genome-encoded polyprotein into mature proteins apart from causing inactivation of cellular proteins required for host immunity against the virus. ${ }^{20}$ Protease inhibitors are most advanced agents in terms of clinical development with boceprevir and telaprevir already being used in clinical practice. In general, these agents have potent antiviral activity only against genotype 1 infection and low barrier to resistance as evidenced by rapid selection of resistance variants when used as monotherapy in clinical trials. $^{21}$ Recently in December 2012, FDA announced black box warning on telaprevir use, stating that telaprevir combination treatment must be immediately stopped in patients experiencing rash with systemic symptoms or a progressive severe rash.

A number of second generation protease inhibitors with potential advantages of broader genotypic activity, different resistance profiles, improved pharmacokinetics (one to two times daily dosing) and better tolerability are in active clinical development. ${ }^{22}$ These include danoprevir (RG7227), narlaprevir (SCH900518), vaniprevir (MK 7009), sovaprevir (ACH-1625), ABT450, MK-5172 and GS-9256 in phase II trials. Others for example, Simeprevir, faldaprevir and asunaprevir are currently in phase III trials. ${ }^{23-27}$ Simeprevir (TMC 435) is the leading agent; being evaluated in multiple phase III studies (QUEST 1, QUEST 2, PROMISE trials) as oncedaily treatment in combination with pegylated interferon and ribavirin for the treatment of genotype 1 and 4 chronic hepatitis $\mathrm{C}$ infection. ${ }^{28-30}$ Trials evaluating the effect of ritonavir boosting on pharmacokinetic profile of newer protease inhibitors such as danoprevir and narlaprevir are also underway. ${ }^{31-32}$

\section{NS5B polymerase inhibitors}

NS5B polymerase (RNA dependent RNA polymerase) is essential for copying HCV-RNA genome and transcribing mRNA; thus it plays a key role in the synthesis of minus and plus strand viral RNA. ${ }^{33}$ Two classes of NS5B polymerase inhibitors -nucleoside and non-nucleoside inhibitors are in development.

a) Nucleos(t)ide analogue inhibitors (NI s): These agents mimic the natural substrates of NS5B polymerase and are incorporated at the active site of the enzyme into the elongated RNA where they act as chain terminators. Since the active site of this polymerase is a highly conserved region of $\mathrm{HCV}$ genome, nucleos(t)ide inhibitors have activity against all genotypes. Also NIs offer high barrier to development of resistance as the NIresistant $\mathrm{HCV}$ variants have displayed poor replicative fitness till date. ${ }^{34,35}$

Innovator company Gilead sciences has recently filed new drug application to USFDA for approval of sofosbuvir; a once-daily oral nucleotide analogue for the treatment of chronic HCV infection after successful completion of four pivotal phase III trials. Results from studies conducted in treatment-naïve patients with genotype 1, 4, 5 and $6 \mathrm{HCV}$ infections showed sustained virologic response rate of $90 \%$ at 12 weeks when sofosbuvir was combined with peginterferon-ribavirin. In treatment naïve patients with genotype $2 / 3$ infection, identical sustained virologic response rate of $67 \%$ was observed at end of 12 weeks; when patients were randomly assigned to receive either Sofosbuvir + RBV for 12 weeks or Peg-IFN + RBV for 24 weeks with fewer adverse events in the sofosbuvir group. ${ }^{36}$ In another placebo controlled trial involving patients with genotype $2 / 3$ infection who were IFN intolerant, SVR at 12 weeks was $78 \%$ in those who received Sofosbuvir + RBV for 12 weeks as compared to $0 \%$ in placebo group. Another study in treatment experienced patients (genotype 2/3) reported superior response rates with 16 week therapy with sofosbuvir + RBV. ${ }^{37}$

Mericitabine; an orally administered prodrug of PSI6130 , is another promising agent that has entered phase III trials. In a study, 24-week response-guided combination regimen of mericitabine $1,000 \mathrm{mg}$ twice daily plus peginterferon alfa- $2 \mathrm{a}+$ ribavirin was found to be well tolerated and more effective than a standard 48week course of peginterferon alfa- $2 \mathrm{a}+$ ribavirin. $^{38}$

b) Non-nucleoside analogue inhibitors (NNIs): These are a heterogeneous group of antiviral compounds that bind to different allosteric enzyme sites, resulting in a conformational protein change before the elongation complex is formed. A number of NNIs such as Setrobuvir (ANA598), BI207127, Filibuvir, VCH-916 and Tegobuvir (GS-9190) are currently being evaluated in early phase (I/II) clinical trials. ${ }^{22,39}$ These molecules bind to one of the four known NNI binding sites which include benzothiadiazine-(palm 1), benzofuran-(palm 2), a benzimidazole-(thumb 1) and thiophene-(thumb 2) sites. $^{23}$ In contrast to NIs, NNIs are not effective across all HCV genotypes. Also these agents have low barrier to resistance as is evidenced by viral breakthroughs in monotherapy studies with NNIs. ${ }^{40-42}$ A number of clinical trials evaluating combinations of NNIs with other drug classes such as NS3/4A inhibitors are currently underway.

\section{NS5A inhibitors}

NS5A protein is involved in various stages of $\mathrm{HCV}$ lifecycle. NS5A protein is a part of membrane-bound 
replication complex, that catalyses viral replication. It also has a role in assembly and release of virions. Apart from its direct involvement in virus replication, it modulates the cellular environment to favour virus replication and persistence inside the host. ${ }^{43,44}$ A number of inhibitors of NS5A protein such as PPI-461, ABT-267, GS-5855 are in early phase clinical development. ${ }^{45}$ These are highly potent agents that are active against all $\mathrm{HCV}$ genotypes but they have a low genetic barrier to resistance. $^{46}$

In treatment naïve patients with $\mathrm{HCV}$ genotype 1 infection, daclatasvir based triple therapy resulted in extended rapid virologic response (eRVR) in up to $83 \%$ of patients as compared to only $9 \%$ patients who received pegIFN-a and ribavirin therapy. Another study reported that when daclatasvir was given as quadruple therapy in combination with asunaprevir, pegylated interferon and ribavirin, it resulted in a high rate of sustained virologic response in genotype 1 prior null responders, making them promising candidates for combination therapies. ${ }^{45,47}$ Daclatasvir is currently undergoing phase III trials.

\section{HOST TARGETING ANTIVIRALS}

\section{Cyclophillin inhibitors}

Host cytosolic protein cyclophilin A participates in $\mathrm{HCV}$ replication by acting as functional regulator of the NS5B polymerase. ${ }^{48}$ Alisporivir; the most advanced agent in clinical development blocks HCV replication by neutralizing the peptidyl-prolylisomerase activity of cyclophilin A. Because it targets the host protein, it has pangenotypic activity. Also it provides a high barrier for development of viral resistance and has an excellent pharmacokinetic and safety profile. ${ }^{49}$ Alisporivir has entered phase III development for HCV genotype-1 after promising results in a phase II trial of genotype-1 treatment naïve patients, in which patients who received alisporivir and PEG-IFN/RBV had superior SVR (76\%) compared with PEG-IFN/RBV alone $(55 \%){ }^{50}$ Alisporivir also has activity against HCV genotypes-2/3 and IFN-free regimens are being evaluated. ${ }^{51}$ FDA has recently ordered clinical hold on the further development of alisporivir due to three cases of severe pancreatitis including one death, though all these cases occurred in patients on combination therapy with alisporivir and interferon. ${ }^{52}$

SCY-635 is another molecule that has shown potent suppression of $\mathrm{HCV}$ replication in studies conducted so far. In a phase $1 \mathrm{~b}$ multi-dose escalation study, different doses of SCY-635 were given in patients with genotype 1 infection. Mean decline in plasma viral load was $2.24 \pm 1.74 \log (10) \mathrm{IU} / \mathrm{ml}$ after 15 days of therapy with SCY-635 at a dose of $900 \mathrm{mg} /$ day. No dose-limiting clinical or laboratory toxicities were identified. Further post hoc analyses indicated that treatment with SCY-635 increased plasma protein concentrations of various interferons suggesting that restoration of the host innate immune response to chronic hepatitis $\mathrm{C}$ infection may represent another mechanism through which cyclophilin inhibitors exert potent antiviral activity. ${ }^{53}$

\section{Antagomirs}

Liver-expressed microRNA-122 is the first identified host miRNA that has been linked to HCV replication. It up regulates viral RNA by binding to two adjacent sites close to the 5' end of HCV RNA. ${ }^{54}$ Antisense oligonucleotide Miravirsen (SPC3649), showed promising results in preclinical studies where systemic administration of SPC3649 to chimpanzees chronically infected with HCV induced a long-lasting suppression of viral RNA in serum without the emergence of resistant mutants. ${ }^{55}$ Results from recently completed phase IIa study which evaluated the safety and efficacy of miravirsen concluded that it led to prolonged dosedependent reductions in HCV RNA levels without evidence of viral resistance. ${ }^{56}$

\section{NEWER ANALOGUES OF CURRENT THERAPIES}

A major barrier to successful treatment with current pegylated interferon and ribavirin therapy is the frequent occurrence of adverse events. In clinical trials, approximately $10-15 \%$ of treated patients discontinued the therapy due to adverse events; however, in routine clinical practice, the rate of treatment discontinuation has been reported to be much higher. ${ }^{57}$ Real world experience report approximately $20 \%$ lower SVR rates than those reported in clinical trials. ${ }^{58}$ Therefore, effort is being made to develop newer analogues of ribavirin and interferon that have better tolerability than currently available agents.

\section{Ribavirin analogues}

In an attempt to reduce haematological side effects with ribavirin, ribavirin analogues are being evaluated in clinical trials. One such compound in phase III development is Taribavirin (viramidine). It is a prodrug that gets converted to ribavirin and is selectively concentrated in the liver, thereby reducing uptake by RBCs and less haemolysis. ${ }^{59}$ In a large phase III clinical trial: viramidine safety and efficacy was evaluated against ribavirin (VISER 1). Though taribavirin showed a superior safety profile with anaemia rates being significantly lesser than ribavirin (5\% vs $24 \%$ ) but in terms of efficacy (SVR rates) taribavirin did not meet the criteria for non-inferiority to ribavirin. ${ }^{60}$ In another phase $2 \mathrm{~b}$ randomized controlled trial in 278 treatment-naive patients infected with genotype 1 , it was concluded that taribavirin at different doses $(20,25$ and $30 \mathrm{mg} / \mathrm{kg}$ ) have efficacy and tolerability comparable to that of weight based ribavirin. Anaemia rates were significantly lower when taribavirin was given at a dose of $20-25 \mathrm{mg} / \mathrm{kg}$ as compared to ribavirin. ${ }^{61}$ Other ribavirin analogs and IMPDH inhibitors have yielded less promising results and have not advanced further in clinical development. ${ }^{59}$ 


\section{Interferon analogues}

Locteron is a slow-release microsphere preparation of recombinant human interferon alpha $2 \mathrm{~b}$ that needs to be administered once every 2 weeks as compared to weekly injections of pegylated interferon. ${ }^{62}$ Results of a 12 week open-label, randomized trial of locteron in 32 patients of chronic HCV genotype 1 infection concluded that treatment was well tolerated, with $97 \%$ patients successfully completing the treatment. Flu-like symptoms were generally mild and brief. ${ }^{63}$ PEG-IFN-lambda is another promising analogue that is active against all $\mathrm{HCV}$ genotypes. A phase II study demonstrated that it causes less marrow toxicity and flu-like symptoms and leads to improved rapid virological response. ${ }^{64}$ Two large phase III studies of Albinterferon alfa-2b in patients with HCV genotype 1 found that it was neither superior in efficacy nor in tolerability to pegylated interferon. Based on the risk/ benefit ratio, the approval of Albinterferon alfa- $2 b$ has been recently suspended. ${ }^{65,66}$

\section{CONCLUSION}

Novel standard of care i.e. triple therapy itself represents a milestone in the management of chronic $\mathrm{HCV}$ infection. But recent insights into lifecycle of $\mathrm{HCV}$ and host cell interactions have definitely opened up new avenues of research with multiple novel drug targets. Most of the agents have shown great promise in clinical trials so far, but therapeutic potential of these molecules needs to be seen in the future when the drugs are used in larger number of people; as phase III trials are done under controlled conditions in highly selected subset of patients. Nevertheless, it seems that combination therapies with direct acting antiviral agents do hold a promise for future in chronic HCV management.

\section{REFERENCES}

1. Holmberg S. Infectious Diseases Related To Travel, 2011. Available at: http://wwwnc.cdc.gov/travel/ yellowbook/2012/chapter-3-infectious-diseasesrelated-to-travel/hepatitis-c. Accessed 15 April 2013.

2. World Health Organization Hepatitis C Fact Sheet 2012 Available at: http://www.who.int/ mediacentre/factsheets/fs164/en/. Accessed 14 April 2013.

3. Chung RT. A watershed moment in the treatment of hepatitis C. N Engl J Med 2012;366:273-5.

4. Lavanchy D. The global burden of hepatitis C. Liver Int 2009;29:74-81.

5. Perz JF, Armstrong GL, Farrington LA, Hutin YJ, Bell BP. The contributions of hepatitis B virus and hepatitis $\mathrm{C}$ virus infections to cirrhosis and primary liver cancer worldwide. J Hepatol 2006;45: 529-38.

6. Lavanchy D. Evolving epidemiology of hepatitis C virus. Clin Microbiol Infect 2011;17: 107-15.

7. Zeuzem S, Hultcrantz R, Bourliere M, Goeser T, Marcellin P, Sanchez-Tapias J et al. Peginterferon alfa-2b plus ribavirin for treatment of chronic hepatitis $\mathrm{C}$ in previously untreated patients infected with HCV genotypes 2 or 3. J Hepatol 2004;40: 993-99.

8. Fried MW, Shiffman ML, Reddy KR, Smith C, Marinos G, Gonçales FL Jr et al. Peginterferon alfa2a plus ribavirin for chronic hepatitis $\mathrm{C}$ virus infection. N Engl J Med 2002;347: 975-82.

9. Manns MP, Wedemeyer H, Cornberg M. Treating viral hepatitis C: Efficacy, side effects and complications. Gut 2006;55: 1350-9.

10. Fried MW. Side effects of therapy of hepatitis $C$ and their management. Hepatology 2002;36(1): 237-44.

11. Bruno S, Crosignani A, Facciotto C, Rossi S, Roffi L, Redaelli A et al. Sustained virologic response prevents the development of esophageal varices in compensated, Child-Pugh class A hepatitis $\mathrm{C}$ virusinduced cirrhosis. A 12- year prospective follow-up study. Hepatology 2010;51: 2069-76.

12. Hadziyannis SJ, Sette H Jr, Morgan TR, Balan V, Diago M, Marcellin P et al. Peginterferonalpha2a and ribavirin combination therapy in chronic hepatitis C: a randomized study of treatment duration and ribavirin dose. Ann Intern Med 2004;140: 346-55.

13. Manns MP, McHutchison JG, Gordon SC, Rustgi VK, Shiffman M, Reindollar R et al. Peginterferon alfa-2b plus ribavirin compared with interferon alfa- $2 b$ plus ribavirin for initial treatment of chronic hepatitis $\mathrm{C}$ : a randomised trial. Lancet 2001;358: 958-65.

14. Ramachandran P, Fraser A, Agarwal K, Austin A, Brown A, Foster GR et al. UK consensus guidelines for the use of the protease inhibitors boceprevir and telaprevir in genotype 1 chronic hepatitis $\mathrm{C}$ infected patients. Aliment Pharmacol Ther 2012;35: 647-62.

15. Shiffman ML, Esteban R. Triple therapy for $\mathrm{HCV}$ genotype 1 infection: telaprevir or boceprevir? Liver Int 2012;32: 54-60.

16. PoordadF, McCone J Jr, Bacon BR, Bruno S, Manns MP, Sulkowski MS et al. Boceprevir for untreated chronic HCV genotype 1 infection. N Engl J Med 2011;364: 1195-06.

17. Hezode C, Dorival C, Zoulim F. Safety of telaprevir or boceprevir in combination with peginterferonalfa/ ribavirin, in cirrhotic non responders. First results of the French Early Access Program (ANRS CO20CUPIC). J Hepatol 2012; 56:A8.

18. Wilby KJ, Greanya ED, Ford JA, Yoshida EM, Partovi N. A review of drug interactions with boceprevir and telaprevir: implications for HIV and transplant patients. Ann Hepatol 2012;11: 179-85.

19. Lee LY, Tong CY, Wong T, Wilkinson M. New therapies for chronic hepatitis C infection: a systematic review of evidence from clinical trials. Int J Clin Pract 2012;66: 342-55.

20. Kim JL, Morgenstern KA, Lin C, Fox T, Dwyer MD, Landro JA et al. Crystal structure of the hepatitis C virus NS3 protease domain complexed 
with a synthetic NS4A cofactor peptide. Cell 1996; 87: 343-55.

21. Kieffer TL, Sarrazin C, Miller JS, Welker MW, Forestier N, Reesink HW, et al. Telaprevir and pegylated interferon-alpha-2a inhibit wild-type and resistant genotype 1 hepatitis $\mathrm{C}$ virus replication in patients. Hepatology 2007;46: 631-9.

22. Christian M. Lange, Stefan Zeuzem. Perspectives and challenges of interferon-free therapy for chronic hepatitis C. J Hepatology2013;58: 583-92.

23. Sarrazin C, Zeuzem S. Resistance to direct antiviral agents in patients with hepatitis $\mathrm{C}$ virus infection. Gastroenterology 2010;138: 447-62

24. Summa V, Ludmerer SW, McCauley JA, Fandozzi C, Burlein C, Claudio G, et al. MK-5172, a selective inhibitor of hepatitis $\mathrm{C}$ virus NS3/4a protease with broad activity across genotypes and resistant variants. Antimicrob Agents Chemother 2012;56: 4161-7.

25. deBruijne J, Bergmann JF, Reesink HW, Weegink CJ, Molenkamp R, Schinkel $\mathrm{J}$ et al. Antiviral activity of narlaprevir combined with ritonavir and pegylated interferon in chronic hepatitis $\mathrm{C}$ patients. Hepatology 2010;52: 1590-9.

26. Manns MP, Bourliere M, Benhamou Y, Pol S, Bonacini M, Trepo C, et al. Potency, safety, and pharmacokinetics of the NS3/4A protease inhibitorBI201335 in patients with chronic HCV genotype-1 infection. J Hepatol 2011;54: 1114-22.

27. Forestier N, Larrey D, Guyader D. Treatment of chronic hepatitis $\mathrm{C}$ Patients with the NS3/4A protease inhibitor danoprevir (ITMN-191/RG7227) leads to robust reductions in viral RNA: a phase $1 \mathrm{~b}$ multiple ascending dose study. J Hepatol 2011;54: 1130-6.

28. TMC435-TiDP16-C208 - phase III trial of TMC435 in treatment-naive, genotype 1 hepatitis $\mathrm{C}$-infected patients (QUEST-1), 2011. Available at:http:// clinicaltrials.gov/show/NCT01289782. Accessed 21 April 2013.

29. TMC435-TiDP16-C216 - phase III trial of TMC435 in treatment-naive, genotype 1 hepatitic $\mathrm{C}$-infected patients (QUEST-2), 2011. Available at:http:// clinicaltrials.gov/ct2/show/NCT01290679. Accessed 21 April 2013.

30. TMC435HPC3007- Phase III trial of TMC435 in genotype 1 Hepatitis C- infected patients who relapsed after previous therapy (PROMISE), 2011. Available at: http://clinicaltrials.gov/ ct2/show/NCT01281839. Accessed 21 April 2013.

31. A pharmacokinetics/pharmacodynamics study of SCH 900518 in previously untreated subjects with chronic hepatitis C (NEXT-1). Available at:http://www.clinicaltrials.gov/ct2/show/NCT0079 7745? term=ritonavir+and+narlaprevir\&rank=1. Accessed 30 April 2013.

32. A study of danoprevir/ritonavir and copegus with RO5024048 and/or pegasys with patients with chronic hepatiis C. Available at:http://www.clinicaltrials.gov/ct2/results?term=rito
navir+and+danoprevir+in+HCV\&Search=Search Accessed 25 May 2013.

33. Lohmann V. Hepatitis C virus RNA replication. Curr Top Microbiol Immunol 2013;369: 167-98.

34. Legrand-Abravanel F, Nicot F, Izopet J. New NS5B polymerase inhibitors for hepatitis C. Expert Opin Investig Drugs 2010;19: 963-75.

35. Lange CM, Sarrazin C, Zeuzem S. Review article: specifically targeted antiviral therapy for hepatitis C - a new era in therapy. Aliment Pharmacol Ther 2010;32: 14-28.

36. Lawitz E, Mangia A, Wyles D, Rodriguez-Torres M, Hassanein T, Gordon SC et al. Sofosbuvir for Previously Untreated Chronic Hepatitis C Infection. N Engl J Med 2013;368: 1878-87.

37. Jacobson IM, Gordon SC, Kowdley KV, Yoshida E M, Rodriguez-Torres M, Sulkowski MS et al. Sofosbuvir for Hepatitis C Genotype 2 or 3 in Patients without Treatment Options. N Engl J Med 2013; 368:1867-77.

38. Pockros PJ, Jensen D, Tsai N, Taylor R, Ramji A, Cooper C, et al. JUMP-C: A randomized trial of mericitabine plus peginterferon alfa-2a/ribavirin for 24 weeks in treatment-naive HCV genotype 1/4 patients. Hepatology 2013 Jan 24. [Epub ahead of print] doi: 10.1002/hep.26275.

39. Aghemo A, De Francesco R. New horizons in Hepatitis C antiviral therapy with direct-acting antivirals. Hepatology. 2013 Mar 6. [Epub ahead of print] doi: 10.1002/hep.26371.

40. Wagner F, Thompson R, Kantaridis C, Simpson P, Troke PJ, Jagannatha $\mathrm{S}$, et al. Antiviral activity of the hepatitis $\mathrm{C}$ virus polymerase inhibitor filibuvir in genotype 1-infected patients. Hepatology 2011;54: 50-9.

41. Pockros PJ. Drugs in development for chronic hepatitis C: a promising future. Expert Opin Biol Ther 2011;11: 1611-22.

42. Larrey D, Lohse AW, de Ledinghen V, Trepo C, Gerlach T, Zarski JP et al. Rapid and strong antiviral activity of the non-nucleosidic NS5B polymerase inhibitor BI 207127 in combination with peginterferon alfa 2a and ribavirin. J Hepatol 2012; 57:39-46.

43. Macdonald A, Harris M. Hepatitis C virus NS5A: tales of a promiscuous protein. J Gen Virol 2004;85: 2485-502.

44. Moradpour D, Penin F, Rice CM. Replication of hepatitis C virus. Nat Rev Microbiol 2007;5:453-63.

45. Suk-Fong Lok A. HCV NS5A inhibitors in development. Clin Liver Dis 2013;17: 111-21.

46. Pawlotsky JM. NS5A Inhibitors in the Treatment of Hepatitis C. J Hepatol 2013 Apr 5. [Epub ahead of print] doi: 10.1016/j.jhep.2013.03.030.

47. Pol S, Ghalib RH, Rustgi VK, Martorell C, Everson GT, Tatum HA et al. Daclatasvir for previously untreated chronic hepatitis $\mathrm{C}$ genotype-1 infection: a randomised, parallel-group, double-blind, placebocontrolled, dose finding, phase $2 \mathrm{a}$ trial. Lancet Infect Dis 2012;12: 671-77. 
48. Vermehren J, Sarrazin C. New hepatitis C therapies in clinical development. Eur J Med Res 2011;16: 303-14

49. Gallay PA, Lin Kai. Profile of alisporivir and its potential in the treatment of hepatitis C. Drug Des Devel Ther 2013;7: 105-15.

50. Flisiak R, Pawlotsky J, Crabbé R, Calistru PI, Kryczka W, Haussinger D et al. Once daily alisporivir (Deb025) plus PEGIFNalfa2a/ribavirin results in superior sustained virologic response (SVR24) in chronic hepatitis C genotype 1 treatment naïve patients. J Hepatol 2011; 54:S2.

51. Pawlotsky JM, Sarin SK, Foster G, Peng CY, Rasenack J, Flisiak R et al. Alisporivir plus ribavirin is highly effective as interferon-free or interferonadd-on regimen in previously untreated HCV-G2 or G3 patients: SVR12 results from VITAL-1 phase $2 \mathrm{~b}$ study. J Hepatol 2012; 56:S553.

52. Keller DM. Pancreatitis events halt development of alisporivir for HCV, 2012. Available at:http://www. medscape.com/viewarticle/762399. Accessed 2 May 2013.

53. Hopkins S, Di Massimo B, Rusnak P, Heuman D, Lalezari J, Sluder A et al. The cyclophilin inhibitor SCY-635 suppresses viral replication and induces endogenous interferons in patients with chronic HCV genotype 1 infection. J Hepatol 2012;57: 47-54.

54. Jopling CL, Yi M, Lancaster AM, Lemon SM, Sarnow P. Modulation of hepatitis C virus RNA abundance by liver-specific MicroRNA. Science 2005;309(5740): 1577-81.

55. Lanford RE, Hildebrandt-Eriksen ES, Petri A, Persson R, Lindow $\mathrm{M}$ et al. Therapeutic silencing of microRNA-122 in primates with chronic hepatitis C virus infection. Science 2010;327(5962): 198-01.

56. Janssen HL, Reesink HW, Lawitz EJ, Zeuzem $\mathrm{S}$, Rodriguez-Torres M, Patel K et al. Treatment of $\mathrm{HCV}$ infection by targeting microRNA. N Engl J Med 2013;368: 1685-94.

57. Hunyady B, Kovács B, Battyáni Z. Side-effects of pegylated interferon plus ribavirin therapy with or without protease inhibitor direct acting antiviral agents during treatment of chronic hepatitis $\mathrm{C}$ virus infection. Orv Hetil 2011;152: 1997-09.
58. Kramer JR, Kanwal F, Richardson P, Mei M, ElSerag HB. Gaps in the achievement of effectiveness of HCV treatment in national VA practice. J Hepatol 2012;56: 320-5.

59. Shields WW, Pockros PJ. Ribavirin Analogs. Clin Liver Dis 2009;13: 419-27.

60. Pockros PJ. New Direct-acting Antivirals in the Development for Hepatitis C Virus Infection. Ther Adv Gastroenterol 2010;3: 191-02.

61. Poordad F, Lawitz E, Shiffman ML, Hassanein T, Muir AJ, Bacon BR, et al. Virologic response rates of weight-based taribavirin versus ribavirin in treatment-naive patients with genotype 1 chronic hepatitis C. Hepatology 2010;52: 1208-15.

62. Jansen PL, De Bruijne J. Controlled-release interferon alpha $2 b$, a new member of the interferon family for the treatment of chronic hepatitis C. Expert Opin Investig Drugs 2012;21: 111-8.

63. Dzyublyk I, Yegorova T, Moroz L, Popovych O, Zaytsev I, Miroshnichenko V, et al. Controlled release recombinant human interferon- $\alpha 2 b$ for treating patients with chronic hepatitis $\mathrm{C}$ genotype 1: a phase 2a clinical trial. J Viral Hepat 2011;18: 271-9.

64. Friborg J, Levine S, Chen C, Sheaffer AK, Chaniewski S, Voss S, et al. Combinations of lambda interferon with direct-acting antiviral agents are highly efficient in suppressing hepatitis $\mathrm{C}$ virus replication. Antimicrob Agents Chemother 2013;57: 1312-22.

65. Zeuzem S, Sulkowski MS, Lawitz EJ, Rustgi VK, Rodriguez-Torres M, Bacon BR, et al. Albinterferon alfa-2b was not inferior to pegylated interferon-alpha in a randomized trial of patients with chronic hepatitis $\mathrm{C}$ virus genotype 1 . Gastroenterology 2010;139:1257-66.

66. Nelson DR, Benhamou Y, Chuang WL, Lawitz EJ, Rodriguez-Torres M, Flisiak $\mathrm{R}$ et al. Albinterferon alfa-2b was not inferior to pegylated interferon-alpha in a randomized trial of patients with chronic hepatitis $\mathrm{C}$ virus genotype 2 or 3 . Gastroenterology 2010;139:1267-76.

doi:10.5455/2319-2003.ijbcp20131001

Cite this article as: Kaur N, Negi H, Pandey A.

Emerging therapies in pipeline for chronic hepatitis $\mathrm{C}$. Int J Basic Clin Pharmacol 2013;2:500-6. 